\title{
PRAKIRAAN HARGA MEAT BONE MEAL (MBM) MENGGUNAKAN JARINGAN SYARAF TIRUAN BACKPROPAGATION
}

\author{
Ahmad Haris Hasanuddin Slamet ${ }^{1}$, Bambang Herry Purnomo ${ }^{2}$, Dedy Wirawan \\ Soedibyo ${ }^{3}$ \\ ${ }^{1)}$ Program Studi Magister Teknologi Agroindustri, Fakultas Teknologi Pertanian, \\ Universitas Jember \\ ${ }^{2)}$ Program Studi Teknologi Industri Pertanian, Fakultas Teknologi Pertanian, \\ Universitas Jember \\ ${ }^{3)}$ Jurusan Teknik Pertanian, Fakultas Teknologi Pertanian, Universitas Jember \\ Jln. Kalimantan 37 Kampus Tegalboto, Jember 68121 \\ e-mail : ${ }^{1}$ haris.hasanuddin94@gmail.com, ${ }^{2}$ binauf06@yahoo.com, \\ ${ }^{3}$ adudee212@gmail.com
}

\begin{abstract}
ABSTRAK
PT. XYZ adalah salah satu produsen pakan unggas di Kabupaten Banyuwangi, Jawa Timur. Permasalahan dalam pengembangan pakan unggas di PT XYZ adalah harga pakan unggas yang berfluktuasi. Meat bone meal (MBM) atau yang disebut dengan tepung daging adalah salah satu bahan baku pakan unggas yang mempengaruhi harga akhir produk pakan unggas. Harga MBM sangat dipengaruhi nilai tukar rupiah terhadap dolar. Prakiraan merupakan salah satu cara yang perlu dilakukan dalam mengatasi fluktuasi harga MBM. Tujuan dari penelitian ini adalah memprakirakan harga MBM menggunakan jaringan syaraf tiruan (JST) backpropagation. Data yang digunakan dalam penelitian ini adalah harga MBM pada periode Januari 2016-Oktober 2018. Berdasarkan hasil penelitian, arsitektur JST terbaik untuk prakiraan harga MBM adalah 12-10-1 (12 node input, 10 node hidden layer, dan 1 node output). Arsitektur ini telah mencapai target pelatihan sebesar 0,002 dengan nilai MAPE pengujian yaitu 13,93\%. Berdasarkan prakiraan dengan JST Harga MBM tertinggi pada bulan Mei 2019 dan harga MBM terendah pada bulan Januari 2019.
\end{abstract}

Kata kunci : pakan unggas, harga meat bone meal (MBM), jaringan syaraf tiruan

\section{ABSTRACT}

PT. XYZ is a poultry feed producer in Banyuwangi Regency, East Java. The problem in developing poultry feed at PT XYZ was the fluctuating price of poultry feed. Meat bone meal (MBM) or what is called meat flour is one of the raw materials for poultry feed that affects the final price of poultry feed products. The price of MBM was greatly influenced by the exchange rate of the rupiah against the dollar. Forecasting is one way that needs to be done in dealing with MBM price fluctuations. The aim of this study was to estimate the price of MBM using backpropagation neural networks (BNN). The data used in this study was the price of MBM in the period January 2016-October 2018. Based on the results of the study, the best BNN architecture for the estimated MBM price was12-10-1 (12 input nodes, 10 hidden nodes, and 1 output node). This architecture has reached the training target of 0.002 with a MAPE test value of $13.93 \%$. 
Based on forecasts with the BNN the highest MBM price in May 2019 and the lowest MBM price in January 2019.

Keywords : poultry feed, price of meat bone meal (MBM), backpropagation neural networks

\section{PENDAHULUAN}

Industri pakan unggas di Indonesia memiliki potensi yang sangat baik untuk dikembangkan. Hal ini dikarenakan kebutuhan pakan unggas di Indonesia yang selalu meningkat setiap tahunnya. Selama periode 2006-2016, laju pertumbuhan permintaan pakan unggas sebesar $8,2 \%$ CAGR (Compound Annual Growth Rate) (Vicentia, 2017). Pertumbuhan yang cukup tinggi ini didukung oleh komoditas dan produk peternakan terutama unggas yang terus meningkat. Adapun, konsumsi pakan ternak pada tahun 2016 mencapai 17,2 juta ton, dengan $97,1 \%$ atau 16,7 juta ton untuk ternak unggas dan $2,8 \%$ atau 481.600 ton untuk ternak lainnya (Alfi, 2018).

Banyuwangi merupakan salah satu kabupaten di Jawa Timur yang memiliki potensi besar dalam pengembangan industri pakan unggas. PT. XYZ merupakan salah satu produsen pakan unggas di Kabupaten Banyuwangi Jawa Timur. PT XYZ memproduksi berbagai macam pakan unggas diantaranya pakan pakan ayam petelur, pakan ayam pedaging, pakan bebek petelur, pakan burung puyuh, dan pakan burung dara.

Permasalahan dari pengembangan pakan unggas di PT. XYZ adalah harga pakan unggas yang berfluktuatif. Fluktuasi harga pakan unggas disebabkan fluktuasi harga bahan baku pembuatan pakan. Salah satu bahan baku pembuatan pakan unggas adalah meat bone meal (MBM). Meat bone meal (MBM) atau yang disebut dengan tepung daging dan tepung tulang memiliki kandungan protein dan kalsium yang tinggi. MBM memiliki kandungan protein kasar bisa mencapai lebih dari $50 \%$. MBM biasanya dibuat dari hasil limbah yang terdapat di Rumah Potong Hewan (RPH) seperti jeroan, tetelan, daging, lemak dan tulang (Dinas Peternakan, 2019).

Secara umum komposisi MBM dalam pakan hunggas hanya sebesar 5\% (Yuniartha, 2018). Namun bahan baku ini diperoleh dari pembelian secara impor. Harga dari MBM sangat dipengaruhi nilai tukar rupiah terhadap dolar. Fluktuasi harga MBM sangat mempengaruhi dari harga akhir produk pakan unggas.

Harga pakan unggas merupakan hal yang sangat penting dalam pertimbangan konsumen untuk membeli produk pakan unggas. Fluktuasi harga pakan unggas juga mempengaruhi keputusan produksi perusahaan. Harga akan mempengaruhi keputusan perusahaan dalam produksi pakan unggas. Perusahaan cenderung meningkatkan produksi saat harga sedang naik dan sebaliknya akan menurunkan produksi saat harga sedang turun.

Prakiraan merupakan salah satu cara yang perlu dilakukan dalam menangani fluktuasi harga MBM. Prakiraan yang tepat dapat dijadikan acuan PT. XYZ dalam optimalisasi alokasi sumber daya sehingga dapat meningkatkan keuntungan yang diperoleh.

Penelitian ini menggunakan metode Jaringan Syaraf Tiruan (JST) untuk prakiraan harga MBM. Jaringan syaraf tiruan merupakan salah satu 
representasi buatan dari otak manusia yang selalu mencoba untuk mensimulasikan proses pembelajaran pada otak manusia tersebut (Kusumadewi dan Hartati, 2006).

Metode jaringan syaraf tiruan yang paling banyak digunakan adalah backpropagation. Backpropagation merupakan algoritma pembelajaran yang terawasi dan biasanya digunakan oleh jaringan dengan banyak lapisan untuk mengubah bobot-bobot yang terhubung dengan neuron-neuron yang ada pada lapisan tersembunyinya. Algoritma backpropagation menggunakan error output untuk mengubah nilai-nilai bobotnya dalam arah mundur (backward) (Boadi et al., 2016). Tahap perambatan maju (forward propagation) harus dikerjakan terlebih dahulu untuk mendapatkan eror (Kusumadewi dan Hartati, 2006).

Prakiraan harga dengan menggunakan jaringan syaraf tiruan backpropagation juga telah dilakukan pada beberapa penelitian. Zou et al., (2007) melakukan penelitian tentang penyelidikan dan perbandingan dari metode jaringan syaraf tiruan dan model rentetan waktu (time series) untuk memprakirakan harga dari gandum. Nilai tingkat kesalahan (MAPE) yang diperoleh sebesar $0,612 \%$. Singhal dan Swarup (2018) melakukan prakiraan harga listrik menggunakan jaringan syaraf tiruan backpropagation. Hasil prakiraan menunjukan nilai MAPE sebesar 4,2\%. Jammazi dan Aloui (2012) melakukan prakiraan terhadap harga minyak mentah. Nilai tingkat kesalahan MAPE sebesar 1,74\%.

Penelitian ini bertujuan untuk mengembangkan arsitektur JST backpropagation dengan tingkat akurasi yang tinggi untuk memprakirakan harga MBM. Penelitian ini dilakukan dengan perlakuan jumlah hidden layer, fungsi aktivasi dan learning rate. Dengan demikian hasil prakiraan diharapkan lebih akurat.

\section{METODOLOGI PENELITIAN}

\subsection{Alat}

Alat penelitian yang digunakan adalah seperangkat komputer dan perangkat lunak yang digunakan yaitu Microsoft excel 2010, dan MATLAB R2015a.

\subsection{Bahan}

Bahan penelitian yang digunakan adalah data sekunder harga Meat Bone Meal (MBM) yang diperoleh dari PT. XYZ Kabupaten Banyuwangi pada periode Juli 2016-Oktober 2018.

\subsection{Tahapan Penelitian}

Data input yang digunakan adalah harga meat bone meal (MBM) dibedakan menjadi data latih dan data uji. Data kemudian dibedakan menjadi $50 \%$ data latih dan $50 \%$ data uji. Data pelatihan meliputi data pada Juli 2016Februari 2018 sedangkan data uji meliputi data pada Maret-Oktober 2018. Pola data input yang digunakan pada peneltian ini terdiri atas data selama periode Januari 2016 - Februari 2018 terdiri atas 16 pola, dengan 8 pola untuk pelatihan dan 8 pola digunakan untuk pengujian. Prosedur penelitian dapat dilihat pada Gambar 1. 


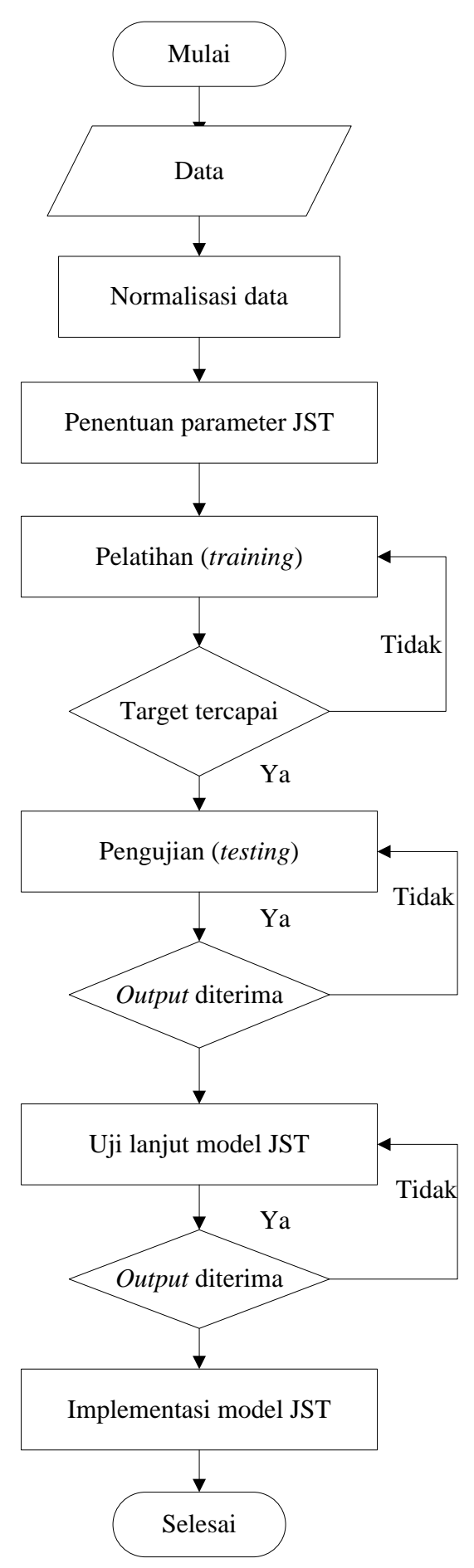

Gambar 1. Tahapan Penelitian

\subsection{Normalisasi data}

Normalisasi data dilakukan untuk mempermudah proses pelatihan jaringan dengan menjadikan rentang data bernilai kecil melalui proses transformasi. Tujuan dari normalisasi data adalah menjadikan taburan data stabil. Normalisasi data berguna untuk menyesuaikan nilai data dengan rentang fungsi aktivasi yang digunakan. Rumus normalisasi data yang digunakan yaitu (Siang, 2005)

$$
X^{\prime}=\frac{0,8 x(X-a)}{b-a}+0,1
$$

\section{Keterangan:}

$\mathrm{X}^{\prime}=$ Transformasi linear menjadi interval $(0,1: 0,9)$

$\mathrm{X}=$ Data input

a = Data minimum

$\mathrm{b} \quad=$ Data maksimum

\subsection{Pelatihan (training)}

Pelatihan jaringan syaraf tiruan menggunakan metode backpropagation. Proses pelatihan merupakan metode pembelajaran terhadap pola data input. Saat proses pelatihan, data input diberikan kepada lapisan input jaringan akan menghitung output dalam lapisan keluaran (Liu et al., 2016). Proses pelatihan dilakukan untuk melatih beberapa bobot input sampai diperoleh bobot yang diinginkan dengan tingkat kesalahan goal MSE antara input dan output tercapai (Cheng et al., 2016). Tahapan pelatihan JST dapat dilihat pada Gambar 2. 


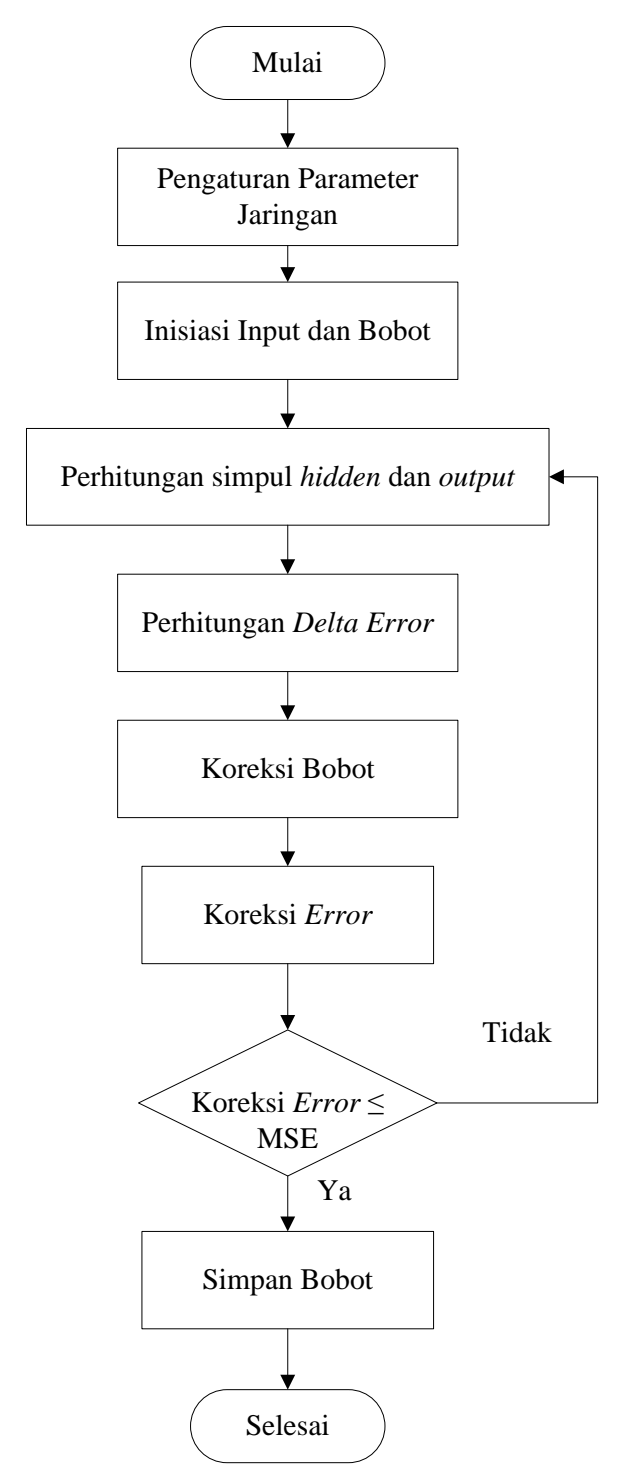

Gambar 2. Pelatihan JST

Berdasarkan Gambar 2, tahapan pertama dalam proses pelatihan adalah pengaturan parameter jaringan syaraf tiruan. Parameter tersebut diantaranya jumlah node hidden layer, fungsi aktivasi, jumlah iterasi maksimum (epoch), learning rate, dan nilai goal mean square error (MSE). Jumlah node hidden layer merupakan berapa jumlah node yang ingin diinput. Penelitian ini menggunakan jumlah node hidden layer adalah 5, 10, dan 15. Fungsi aktivasi yang digunakan yaitu sigmoid bipolar (tansig) dan linear (purelin). Jumlah iterasi (epoch) maksimum menentukan seberapa kali pelatihan/iterasi akan dilakukan. Semakin banyak jumlah iterasi maka semakin lama proses pelatihan. Jumlah iterasi yang digunakan adalah 70.000. Nilai learning rate (lr) merupakan nilai konstanta dengan nilai maksimum 1. Nilai lr yang digunakan yaitu 0,005. Ketiga parameter ini dikombinasikan sampai diperoleh performance goal (MSE) yang diinginkan yaitu 0,002.

Tahapan selanjutnya adalah inisiasi input dan bobot. Input yang digunakan adalah variabel-variabel yang mempengaruhi permintaan dan harga pakan unggas. Bobot awal pada lapisan input ke lapisan tersembunyi dan dari lapisan tersembunyi ke lapisan output merupakan bilangan acak kecil atau menggunakan metode NguyenWidrow. Metode Nguyen-Widrow secara sederhana dapat diimplementasikan dengan prosedur sebagai berikut (Kusumadewi dan Hartati, 2006).

$$
\begin{aligned}
& \mathrm{n} \quad=\text { jumlah node pada lapisan input } \\
& \mathrm{p}=\text { jumlah node pada lapisan } \\
& \text { tersembunyi (hidden layer) } \\
& \beta=\text { faktor penskalaan }(=0.7(\mathrm{p}) 1 / \mathrm{n})
\end{aligned}
$$

$$
\left\|V_{j}\right\|=\sqrt[2]{v_{j 1}^{2}+v_{j 2}^{2}+\ldots v_{j n}^{2}}
$$

Semua bobot (vji) ditentukan dengan bilangan acak pada kisaran [-0.5 , 0.5]. selanjtunya menghitung nilai vj dengan persamaan 3.6. Bobot-bobot ditentukan ulang dengan persamaan:

$$
\mathrm{Vij}=\beta \mathrm{Vij}+\|\mathrm{Vj}\| \text {. }
$$

Syntax yang digunakan di matlab untuk menampilkan perintah pelatihan JST yaitu:

$>$ net=newff(minmax $(\mathrm{p}),[15$

1],\{'tansig','purelin'\},'traingdm');

$>$ net.trainParam.goal $=0.002$;

> net.trainParam.epochs $=70000$; 


$$
\begin{aligned}
& \text { > net.IW }\{1,1\}=\mathrm{IW} ; \\
& \text { > net.LW }\{2,1\}=\mathrm{LW} ; \\
& \text { > } \text { net.b }\{1\}=\mathrm{b} 1 ; \\
& \text { > net.b }\{2\}=\mathrm{b} 2 ; \\
& \text { > net=train(net,p,t); }
\end{aligned}
$$

Keterangan:

$$
\begin{array}{ll}
\text { net } & \begin{array}{l}
\text { = model jaringan syaraf yang } \\
\text { terpilih }
\end{array} \\
\mathrm{p} & \begin{array}{l}
\text { = inputan jaringan syaraf yang } \\
\text { sudah }
\end{array} \\
\mathrm{t} & =\text { matriks target jaringan syaraf } \\
\mathrm{IW} & =\text { Bobot input } \\
\mathrm{LW} & =\text { Bobot lapisan } \\
\mathrm{b} 1 & =\text { Bobot bias input } \\
\mathrm{b} 2 & =\text { Bobot bias lapisan }
\end{array}
$$

\subsection{Pengujian (testing)}

Pengujian dilakukan untuk menguji kinerja jaringan syaraf tiruan. Proses pengujian dilakukan untuk menilai prakiraan harga MBM dibandingkan data aktual (target). Tahap pengujian dilakukan pada model yang telah mencapai target MSE pada saat pelatihan. Pengujian digunakan untuk mengukur akurasi dari model jaringan syaraf tiruan yang telah dikembangkan. Ukuran statistik yang digunakan untuk menguji model adalah mean absolute presentage error (MAPE). Perhitungan MAPE dapat dilihat pada rumus di bawah ini.

$$
\text { MAPE }=\frac{100}{\mathrm{~N}} \sum\left(\frac{\mathrm{y}_{1}-\mathrm{yt}^{1}}{\mathrm{y}_{1}}\right)
$$

Semakin kecil nilai MAPE maka semakin bagus model yang telah dikembangkan. Skala error dalam penelitian ini dapat dilihat pada tabel 1
Tabel 1. Skala performa prakiraan

\begin{tabular}{ll}
\hline MAPE & Hasil Prakiraan \\
\hline$<10 \%$ & Sangat baik \\
$10-20 \%$ & Baik \\
$20-50 \%$ & Layak/cukup \\
$>50 \%$ & Buruk \\
\hline
\end{tabular}

Sumber: (Azhar et al., 2017)

Syntax yang dimasukkan untuk proses simulasi/pengujian adalah:

$$
\begin{aligned}
& \mathrm{Z}=\operatorname{sim}(\text { net, } \mathrm{i}) \\
& \quad \text { Keterangan: } \\
& \mathrm{Z} \quad=\text { output JST } \\
& \text { net } \quad=\text { model JST yang telah terpilih } \\
& \mathrm{i} \quad=\text { matriks input data uji jaringan }
\end{aligned}
$$

\subsection{Postprocessing}

Setelah jaringan output yang diinginkan, selanjutnya nilai bobot output dilakukan proses denormalisasi. Postprocessing merupakan tahapan mengubah output kembali ke bentuk aslinya (denormalisasi). Setelah jaringan menghasilkan output yang diinginkan, selanjutnya nilai bobot output dilakukan proses denormalisasi. Tahapan denormalisasi untuk nilai baru menggunakan rumus sebagai berikut (Siang, 2005):

$$
X=\frac{\left(x^{\prime}-0,1\right)(b-a)}{0,8}+a
$$

Keterangan:

$$
\begin{array}{ll}
\mathrm{X} & =\text { data denormalisasi } \\
\mathrm{x}, & =\text { data hasil normalisasi } \\
\mathrm{a} & =\text { data minimum } \\
\mathrm{b} & =\text { data maksimum }
\end{array}
$$




\subsection{Implementasi model jaringan syaraf tiruan}

Implementasi model jaringan syaraf tiruan dilakukan setelah proses pelatihan dan pengujian. Hasil pelatihan yang didapat yaitu bobot-bobot akhir. Bobot-bobot tersebut selanjutnya diimplementasikan untuk MBM. Arsitektur jaringan syaraf tiruan (JST) yang dikembangkan pada penelitian ini dapat dilihat pada gambar 3 .

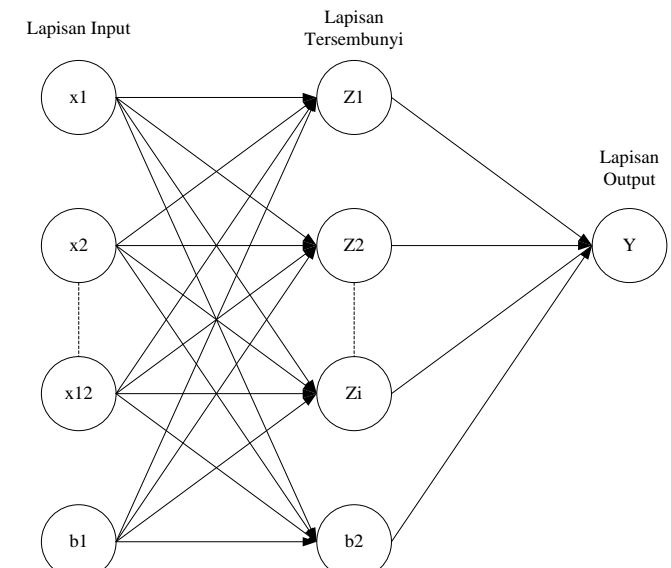

Gambar 3. Arsitektur Jaringan Syaraf Tiruan

\section{III.HASIL DAN PEMBAHASAN}

Harga MBM pada periode Juli 2016-Oktober 2018 dapat dilihat pada Gambar 4.

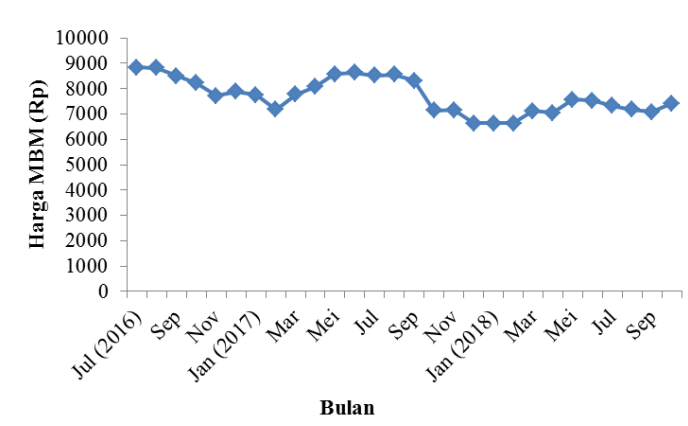

Gambar 4. Harga MBM Pada Periode Juli 2016-Oktober 2018

Berdasarkan Gambar 4, dapat dilihat bahwa harga MBM cenderung berfluktuatif setiap bulanya. Harga MBM tertinggi terjadi pada bulan Juni tahun 2018 sedangkan harga terendah terjadi pada bulan Januari tahun 2018 . MBM merupakan bahan baku pembuatan pakan ayam unggas yang diperoleh dari impor. Naik turunnya harga MBM sangat dipengaruhi dari naik turunnya kurs rupiah terhadap dolar.

\subsection{Analisis Hasil Pelatihan JST}

Data yang digunakan untuk pelatihan JST yaitu data dalam periode Juli 2016-April 2018 sedangkan data uji yaitu data pada periode Mei-Oktober 2018. Parameter model JST yang dikembangkan meliputi node hidden layer $(5,10$, dan 15), learning rate sebesar 0,005, goal (MSE) sebesar 0,001, fungsi aktivasi (tansig-purelin), dan maksimum iterasi sebanyak 70.000. Hasil pelatihan dan pengujian dapat dilihat pada tabel 2 .

Tabel 2. Hasil Pelatihan dan Pengujian Prakiraan Harga MBM

\begin{tabular}{ccc}
\hline $\begin{array}{c}\text { Node } \\
\text { hidden } \\
\text { layer }\end{array}$ & $\begin{array}{c}\text { MSE } \\
\text { Pelatihan }\end{array}$ & $\begin{array}{l}\text { MAPE } \\
\text { Pengujian (\%) }\end{array}$ \\
\hline 5 & 0,002 & 14,53 \\
10 & 0,002 & 13,93 \\
15 & 0,002 & 19,76 \\
\hline
\end{tabular}

Berdasarkan tabel 2, semua node hidden layer mencapai target saat pelatihan. Hasil pengujian menunjukkan jumlah node hidden layer dengan MAPE terkecil yaitu 10 node hidden layer. Dengan demikian, prakiraan harga MBM menggunakan 10 node hidden layer. Secara umum semakin banyak jumlah node hidden layer semakin baik performa JST. Namun, kondisi ini bisa terjadi saat pola data pengujian hampir sama dengan pola 
data pelatihan. Hal ini sesuai dengan penelitian yang dilakukan oleh (Zhao, Nan, Cui, dan Guo, 2007) bahwa 18 node hidden layer menghasilkan error lebih rendah dibandingkan 20 node hidden layer.

\subsection{Hasil Prakiraan Jaringan Syaraf Tiruan}

Setelah dilakukan pelatihan dan pengujian tahapan selanjutnya adalah dilakukan prakiraan dengan arsitektur jaringan syaraf tiruan terbaik. Hasil prakiraan harga MBM dapat dilihat pada Gambar 5.

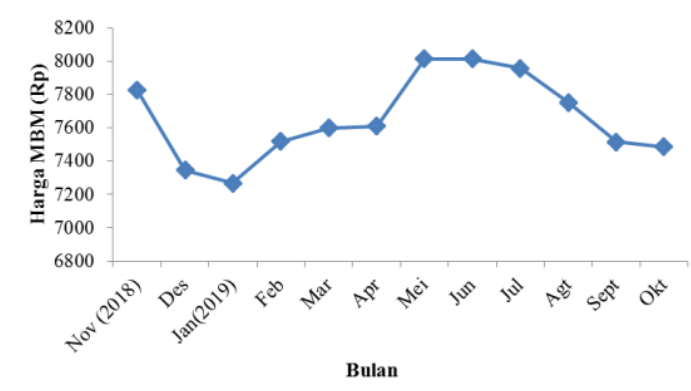

Gambar 5. Prakiraan harga MBM periode November 2018-Oktober 2019

Berdasarkan Gambar 5, harga MBM juga cenderung fluktuatif di setiap bulannya. Harga tertinggi terjadi pada bulan Mei 2019 dan harga terendah terjadi pada bulan Januari 2019. Fluktuasi harga MBM sangat dipengaruhi dari naik turunnya kurs rupiah terhadap dolar. Berdasarkan data-data sebelumnya harga MBM mengalami kenaikan pada bulan AprilJuni dan mengalami penurunan pada bulan Januari.

\section{Penutup}

\subsection{Kesimpulan}

Arsitektur Jaringan syaraf tiruan yang dapat digunakan untuk prakiraan Meat Bone Meal (MBM) adalah 12-101 (12 node input, 5 node hidden layer, dan 1 node output. Arsitektur ini telah mencapai target pelatihan sebesar 0,002 dengan nilai MAPE pengujian yaitu $13,93 \%$. Berdasarkan prakiraan dengan JST Harga MBM tertinggi pada bulan Mei 2019 dan harga MBM terendah pada bulan Januari 2019.

\section{DAFTAR PUSTAKA}

Alfi, N. A. (2018). Pakan Ternak: Konsumsi Diyakini Tumbuh 8\%. Retrieved from https://kalimantan.bisnis.com

Azhar, M., Riksakomara, E., \& Terkait, A. P. (2017). Peramalan Jumlah Produksi Ikan dengan Menggunakan Backpropagation Neural Network (Studi Kasus: UPTD Pelabuhan Perikanan Banjarmasin). Journal of Engineering ITS, 6(1), 142-148.

Boadi, P. O., Bondinuba, F. K., Meng, J., Shi, E., Li, J., Antwi, P., \& Deng, K. (2016). Estimation of biogas and methane yields in an $U A S B$ treating potato starch processing wastewater with backpropagation artificial neural network. Bioresource Technology, 228 , 106-115. https://doi.org/10.1016/j.biortech. 2016.12.045

Cheng, J., Wang, X., Si, T., Zhou, F., Zhou, J., \& Cen, K. (2016). Ignition temperature and activation energy of power coal blends predicted with backpropagation neural network models. Fuel, 173(January), 230238.https://doi.org/10.1016/j.fuel. 2016.01.043

Dinas Peternakan. (2019). Jangan Berikan MBM (Meat and Bone Meal) Sebagai Campuran Pakan Ternak Ruminansia. Retrieved from disnak.lebakkab.go.id 
Jammazi, R., \& Aloui, C. (2012). Crude oil price forecasting: Experimental evidence from wavelet decomposition and neural network modeling. Energy Economics, 34(3), 828-841. https://doi.org/10.1016/j.eneco.20 11.07.018

Kusumadewi, S., \& Hartati, S. (2006). Neuro Fuzzy: Integrasi Sistem Fuzzy Dan Jaringan Syaraf. Yogyakarta: Graha Ilmu.

Liu, S., Xu, L., \& Li, D. (2016). Multiscale prediction of water temperature using empirical mode decomposition with backpropagation neural networks. Computers and Electrical Engineering, 49, 1-8. https://doi.org/10.1016/j.compelec eng.2015.10.003

Siang, J. J. (2005). Jaringan Syaraf Tiruan dan Pemrogramannya Menggunakan Matlab. Yogyakarta: Andi.

Singhal, D., \& Swarup, K. S. (2018). Electricity Prices Forecasting using Artificial Neural Networks. IEEE Latin America Transactions, 16(1), 105-111. https://doi.org/10.1109/TLA.2018 .8291461

Yuniartha, L. (2018). Bungkil Kedelai Naik Berpotensi Naikkan Harga Pakan Ternak. Retrieved from https://industri.kontan.co.id

Zhao, Y., Nan, J., Cui, F., \& Guo, L. (2007). Water quality forecast through application of BP neural network at Yuqiao reservoir. Journal of Zhejiang UniversitySCIENCE A, 8(9), 1482-1487. https://doi.org/10.1631/jzus.2007. a1482
Zou, H. F., Xia, G. P., Yang, F. T., \& Wang, H. Y. (2007). An investigation and comparison of artificial neural network and time series models for Chinese food grain price forecasting. Neurocomputing, 70(16-18), 2913-2923. https://doi.org/10.1016/j.neucom. 2007.01.009 